8-17-2012

\title{
Managerial Action And Resource Advantage Theory: Conceptual Frameworks Emanating From A Positive Theory Of Competition
}

Shelby D. Hunt

Texas Tech University

Sreedhar Madhavaram

Cleveland State University, s.madhavaram@csuohio.edu

Follow this and additional works at: https://engagedscholarship.csuohio.edu/bus_facpub

Part of the Business Administration, Management, and Operations Commons

How does access to this work benefit you? Let us know!

\section{Publisher's Statement}

NOTICE: this is the author's version of a work that was accepted for publication in the Journal of Business \& Industrial Marketing. Changes resulting from the publishing process, such as peer review, editing, corrections, structural formatting, and other quality control mechanisms may not be reflected in this document. Changes may have been made to this work since it was submitted for publication. A definitive version was subsequently published in Journal of Business \& Industrial Marketing, 27, 7, 08-17-2012, 10.1108/08858621211257356

\section{Original Published Citation}

Hunt, S.D. \& Madhavaram, S. (2012). Managerial action and resoruce-advantage theory: Conceptual frameworks emanating from a positive theory of competition. Journal of Business \& Industry Marketing, 27(7), 582-591. doi: 10.1108/08858621211257356

This Article is brought to you for free and open access by the Monte Ahuja College of Business at EngagedScholarship@CSU. It has been accepted for inclusion in Business Faculty Publications by an authorized administrator of EngagedScholarship@CSU. For more information, please contact library.es@csuohio.edu. 


\title{
Managerial action and resource-advantage theory: conceptual frameworks emanating from a positive theory of competition
}

\author{
Shelby D. Hunt \\ Department of Marketing, Texas Tech University, Lubbock, Texas, USA, and \\ Sreedhar Madhavaram \\ Department of Marketing, Cleveland State University, Cleveland, Ohio, USA
}

\begin{abstract}
Purpose - The purpose of this paper is to illustrate that conceptual frameworks developed from a general theory of competition, i.e. resourceadvantage (R-A) theory, can facilitate managerial action.

Design/methodology/approach - After a brief overview of resource-advantage (R-A) theory, five conceptual frameworks are developed and offered for the purposes of managerial action.

Findings - This paper identifies several conceptual frameworks and after noting that conceptual frameworks that do not have positive theoretical foundations may not be as useful as those that do, develops five conceptual frameworks that are based on R-A theory.

Practical implications - The conceptual frameworks developed in this paper have great potential for facilitating managerial action.

Originality/value - Conceptual frameworks that have positive theoretical foundations can be very useful for practitioners. In fact, the frameworks proposed in this paper can replace frameworks that are currently in use for managerial action.
\end{abstract}

Keywords Managerial action, Resource-advantage theory, Conceptual frameworks, Firm Resources and External Environment framework, Resource management, Managers

Paper type Conceptual paper

\begin{abstract}
Managerial actions both influence firm performance and form the core of firm's management processes (Ghoshal and Bartlett, 1994). For Porter (1991), managerial actions underlie strategic positions as well as organizational capabilities. For example, managerial actions can proactively shape organizational systems to fit the dynamic external environment (Venkataraman and Prescott, 1990). As another example, Rajgopal et al. (2002) find that managerial actions of business-to-business internet firms have a positive impact on stock returns and earnings. These actions include the acquisition of major customers, the introduction of new products and services, promotional and marketing actions, decisions to expand into international markets, actions taken to address the concerns of diverse stakeholders the developing of technology, marketing, and distribution alliances, and the completion of acquisitions. It is unsurprising, therefore, that decades of work on business strategy focused on factors that influence managerial action (Ghoshal and Bartlett, 1994).

Conjoined with research investigating the effects of managerial action, strategy educators have focused on preparing future managers by providing knowledge conducive to developing actions favorable to positive firm results. However, what kinds of knowledge do managers need
\end{abstract}

for action? Garda (1988) suggests that practitioners, in general, need knowledge of concepts, theories, frameworks, and analytical techniques to solve managerial problems. Similarly, Rossiter (2001) suggests, in the context of marketing strategy, that marketing managers need concepts, structural frameworks, strategic principles, and research principles. Readers should note that:

- concepts and conceptual (structural) frameworks are common to the recommendations of both researchers; and - the "strategic principles" recommended by Rossiter (2001) are, in fact, theories.

Therefore, Garda's (1988) recommendations seem to parallel those of Rossiter (2001).

Although all the kinds of knowledge recommended by Garda (1988) are necessary for managerial action, Day and Montgomery (1999) claim that frameworks and typologies are often more useful than theories. That is, the fact that conceptual frameworks help managers think about concepts and their relationship to the specific contexts of problems makes conceptual frameworks particularly effective in facilitating managerial actions (Garda, 1988). However, unless these frameworks and typologies have a robust theoretical foundation, they may not provide useful guidance (Hunt and Madhavaram, 2006). A review of the business and marketing strategy literatures reveals several conceptual frameworks that can facilitate managerial actions. For example, in the context of marketing strategy, the product-marketing audit can facilitate managerial action. Similarly, in the context of business strategy, Porter's five forces framework can facilitate managerial action. However, most existing conceptual frameworks lack a comprehensive, positive theoretical foundation. Such comprehensive theories 
explain why and when conceptual frameworks work well (or not)

Therefore, the thesis underlying this article is that theories are fertile grounds for providing conceptual frameworks to guide managerial action. Specifically, because resourceadvantage (R-A) theory is a general theory of competition that provides an integrative, positive, theoretical foundation for business and marketing strategy (Hunt and Derozier, 2004), this article proposes R-A theory as a source of several conceptual frameworks that can facilitate managerial action.

The remainder of the article is organized as follows. First, we identify several conceptual frameworks that can facilitate managerial action. Here, we also discuss one of the most popular and widely used conceptual frameworks in more detail. This is the strengths, weaknesses, opportunities, and threats (SWOT) framework. Second, we provide a brief overview of R-A theory. Third, we discuss several conceptual frameworks developed from R-A theory and show how they can be useful for facilitating managerial action. In particular, we propose the Firm Resources and External Environment (FREE) conceptual framework as an alternative to SWOT. We conclude with a discussion of the usefulness of our conceptual frameworks for managerial action.

\section{Conceptual frameworks}

Conceptual frameworks help managers think about problems (Garda, 1988). Rossiter (2001, p. 5) elaborates further and conceptualizes a structural (conceptual) framework as a "descriptive list of concepts in serial or grid format, that helps organize, and therefore, begins to solve, a marketing problem". The business and marketing strategy literatures have produced numerous conceptual frameworks. Examples include the BCG growth-share matrix, the procedures for conducting marketing audits, the steps for choosing marketing mixes, and the processes for developing marketing plans. Porter's five forces framework, the SWOT framework, and the value chain concept may all be considered as conceptual frameworks that help managers think about problems. Furthermore, some researchers (e.g. Haynes and Helms, 1991; Henson et al., 2003; Peterson, 1987; Van Doren and Smith, 1999) have developed and recommended their own conceptual frameworks that are based on other conceptual frameworks such as the marketing plan and the marketing audit. Biggadike (1981) explicitly identifies the marketing mix, marketing plan, and marketing audit as conceptual frameworks that can facilitate marketing managerial action. Similarly, Garda (1988) explicitly identifies Porter's five forces model, the BCG growth-share matrix, and marketing plan as conceptual frameworks that can facilitate managerial action.

Though all the conceptual frameworks identified in the preceding paragraph can be useful for managerial action, space constraints dictate that we provide details only for what is arguably the most popular conceptual framework - SWOT. The strengths, weaknesses, opportunities, and threats (SWOT) framework has its origins in the work of business policy academics at Harvard Business School (Hill and Westbrook, 1997; Panagiotou, 2003). As Hill and Westbrook (1997, p. 47) note, the work of Kenneth Andrews has had a significant impact on the notion that good strategy involves the "fit between the external situation a firm faces (threats and opportunities) and its own internal qualities or characteristics (strengths and weaknesses)". For more than four decades, SWOT analysis has remained popular with business and marketing strategy practitioners and educators. The proponents of SWOT advocate its use as a precursor to strategy formulation and managerial decision-making and action (Pickton and Wright, 1998).

The SWOT framework's advantages have encouraged its continued use by practitioners and academics as a facilitator of managerial action. Specifically, Hill and Westbrook (1997) claim that SWOT is a straightforward approach that requires little preparation. For Pickton and Wright (1998), SWOT's use allows management to focus its attention on the key issues that affect business development and growth. Also, on the electronic bulletin board of the American Marketing Association, in 2002, Scott J. Armstrong initiated a discussion about the usefulness of the SWOT framework. On this bulletin board, several practitioners and academics advocated the use of SWOT by reasoning that it can be:

- used as a starting point for planning and analysis; and

- useful as a diagnostic tool that helps evaluate the organizational and environmental characteristics of the firm.

However, many academics and practitioners are highly critical of SWOT and recommend that it be abandoned. In the context of business strategy, Hill and Westbrook (1997) recommend that the time is right for a "product recall" of SWOT. In addition, Pickton and Wright (1998) express numerous concerns, such as the inadequate definition of factors, lack of prioritization of factors, and over-subjectivity and compiler bias in the generation of factors. They recommend a greatly modified SWOT approach as an improved alternative. Similarly, in the context of marketing strategy, on the electronic bulletin board of the American Marketing Association, practitioners and academics listed several reasons for abandoning SWOT. These include that it: - mixes idea generation and evaluations;

- ignores defining the firm's objectives;

- wrongly considers negative information by looking at weaknesses and threats;

- leads to paralysis of thought and action; and

- leaves out important factors.

In addition, Panagiotou (2003) criticizes that SWOT remains rooted in vagueness, relies on an oversimplified process, and has not kept up with the evolution of strategic planning and strategy formulation literature. Specifically, SWOT has not kept up with resource-based (R-B) strategy and R-A theory literatures. Therefore, in this paper, among the five conceptual frameworks developed from R-A theory, we propose the Firm Resources and External Environment (FREE) conceptual framework as an alternative to the SWOT framework. Next, we provide a brief overview of R-A theory.

\section{An overview of R-A theory}

Resource-advantage theory is an evolutionary, process theory of competition that is interdisciplinary in the sense that it has been developed in the literatures of several different disciplines such as marketing, management, economics, ethics, and general business (see Table I). R-A theory is also interdisciplinary in that it draws on and has affinities with numerous other theories and research traditions, including evolutionary economics, "Austrian" economics, the historical tradition, industrial-organization economics, the resourcebased tradition, the competence-based tradition, institutional 
Table I Development of resource-advantage theory

\begin{tabular}{lll}
\hline Discipline & Exemplar sources & Central issues \\
\hline 1. Marketing & $\begin{array}{l}\text { Foss (2000), Hodgson (2000), Hunt (1997a, 1999, 2000b, c, } \\
\text { 2001, 2002a, b, 2011), Hunt and Arnett (2001, 2003, 2004), } \\
\text { Hunt and Derozier (2004), Hunt et al. (2002), Hunt and } \\
\text { Morgan (1995, 1996, 1997), Morgan and Hunt (2002) } \\
\text { Hunt (1995, 2000a), Hunt and Lambe (2000) }\end{array}$ & $\begin{array}{l}\text { orientation, competitive advantage, sustainable marketing } \\
\text { 2. Management }\end{array}$ \\
Hunt (1997b, c, d, 2000d, 2002c) & $\begin{array}{l}\text { Productivity, economic growth, competences, strategic } \\
\text { management, marketing's contribution to business strategy } \\
\text { 3. Economics }\end{array}$ & $\begin{array}{l}\text { Evolutionary economics, endogenous growth models, wealth } \\
\text { of nations, neoclassical economics, general theory of } \\
\text { competition } \\
\text { 4. Ethics }\end{array}$ \\
5. General business & Hunt (1998), Hunt and Duhan (2002) & $\begin{array}{l}\text { Competitive irrationality, moral philosophy } \\
\text { Productivity, economic growth, resource allocation, resource } \\
\text { creation, competition in the third millennium, efficiency } \\
\text { advantage, effectiveness advantage }\end{array}$ \\
\hline
\end{tabular}

economics, transaction cost economics, and economic sociology.

Resource-advantage theory is a general theory of competition that describes the process of competition. Figures 1 and 2 provide schematic depictions of R-A theory's key constructs and Table II provides its foundational premises.

\section{The structure and foundations of R-A theory}

Using Hodgson's (1993) taxonomy, R-A theory is an evolutionary, disequilibrium-provoking, process theory of competition, in which innovation and organizational learning are endogenous, firms and consumers have imperfect information, and in which entrepreneurship, institutions, and public policy affect economic performance. Evolutionary theories of competition require units of selection that are:

- relatively durable - that is, they can exist, at least potentially, through long periods of time; and

- heritable - that is, they can be transmitted to successors.
For R-A theory, both firms and resources are proposed as the heritable, durable units of selection, with competition for comparative advantages in resources constituting the selection process.

At its core, R-A theory combines heterogeneous demand theory with the resource-based theory of the firm (see premises P1, P6, and P7 in Table II). Contrasted with perfect competition, heterogeneous demand theory views intraindustry demand as significantly heterogeneous with respect to consumers' tastes and preferences. Therefore, viewing products as bundles of attributes, different market offerings or "bundles" are required for different market segments within the same industry. Contrasted with the view that the firm is a production function that combines homogeneous, perfectly mobile "factors" of production, the resource-based view holds that the firm is a combiner of heterogeneous, imperfectly mobile entities that are labeled "resources". These heterogeneous, imperfectly mobile resources, when combined with heterogeneous demand, imply significant diversity as to the sizes, scopes, and levels of profitability of firms within the same industry. The resource-based theory of

Figure 1 Schematic of the resource-advantage theory of competition

Societal Resources

Societal Institutions

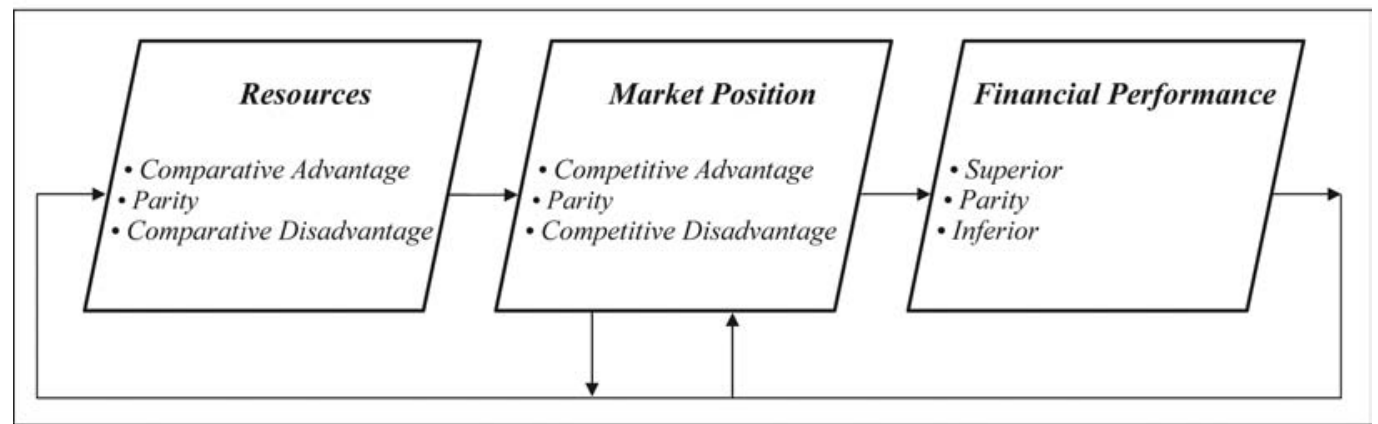

Competitors-Suppliers

Consumers

Public Policy

Notes: Competition is the disequilibrating, ongoing process that consists of the constant struggle among firms for a comparative advantage in resources that will yield a marketplace position of competitive advantage and, thereby, superior financial performance. Firms learn through competition as a result of feedback from relative financial performance "signaling" relative market position, which, in turn signals relative resources Source: Adapted from Hunt and Morgan (1997) 
Figure 2 Competitive position matrix

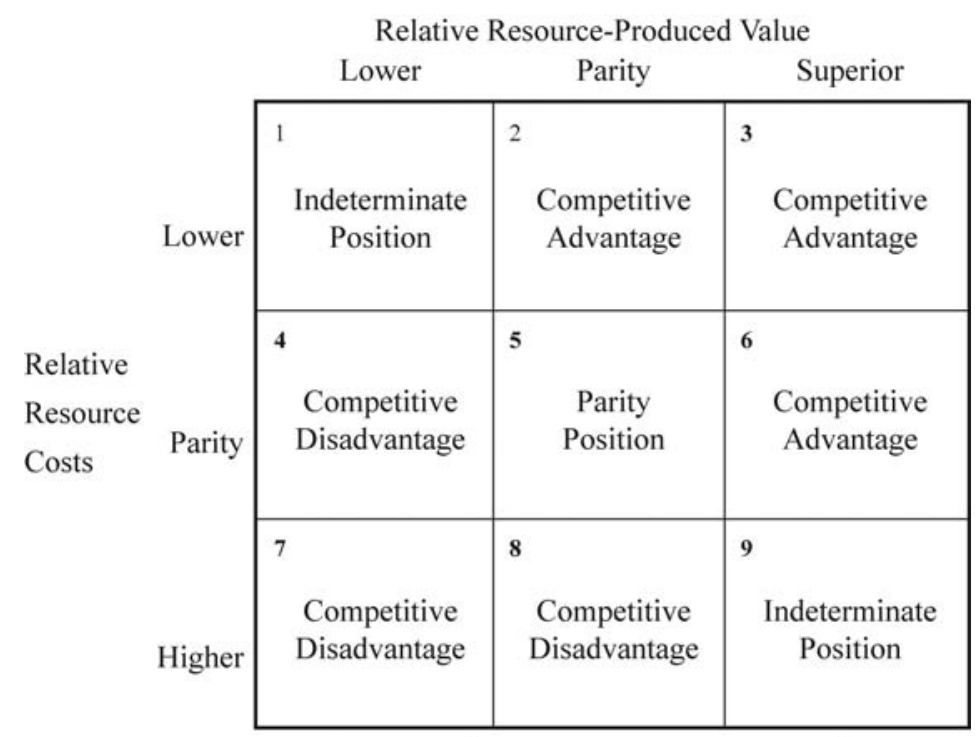

Notes: The marketplace position of competitive advantage identified as cell 3 results from the firm, relative to its competitors, having a resource assortment that enables it to produce an offering for some market segment(s) that (a) is perceived to be of superior value and (b) is produced at lower costs

Source: Adapted from Hunt and Morgan (1995)

Table II Foundational premises of resource-advantage theory

\begin{tabular}{ll}
\hline $\mathbf{P}_{1}$ & $\begin{array}{l}\text { Demand is heterogeneous across industries, heterogeneous within } \\
\text { industries, and dynamic }\end{array}$ \\
$\mathbf{P}_{2}$ & Consumer information is imperfect and costly \\
$\mathbf{P}_{3}$ & Human motivation is constrained self-interest seeking \\
$\mathbf{P}_{4}$ & The firm's objective is superior financial performance \\
$\mathbf{P}_{5}$ & The firm's information is imperfect and costly \\
$\mathbf{P}_{6}$ & The firm's resources are financial, physical, legal, human, \\
& organizational, informational, and relational \\
$\mathbf{P}_{7}$ & Resource characteristics are heterogeneous and imperfectly mobile \\
$\mathbf{P}_{8}$ & $\begin{array}{l}\text { The role of management is to recognize, understand, create, select, } \\
\text { implement, and modify strategies }\end{array}$ \\
$\mathbf{P}_{9}$ & Competitive dynamics are disequilibrium-provoking, with innovation \\
& endogenous
\end{tabular}

Source: Adapted from Hunt and Morgan (1997)

the firm parallels, if not undergirds, what Foss (1993) calls the "competence perspective" in evolutionary economics and the “capabilities" approaches of Teece and Pisano (1994).

As illustrated in Figures 1 and 2, R-A theory stresses the importance of:

- market segments;

- heterogeneous firm resources;

- comparative advantages/disadvantages in resources; and

- marketplace positions of competitive advantage/ disadvantage.

In brief, market segments are defined as intra-industry groups of consumers whose tastes and preferences with regard to an industry's output are relatively homogeneous. Resources are defined as the tangible and intangible entities available to the firm that enable it to produce efficiently and/or effectively a market offering that has value for some marketing segment(s). Thus, resources are not just land, labor, and capital, as in neoclassical theory. Rather, resources can be categorized as financial (e.g. cash resources, access to financial markets), physical (e.g. plant, equipment), legal (e.g. trademarks, licenses), human (e.g. the skills and knowledge of individual employees), organizational (e.g. competences, controls, policies, culture), informational (e.g. knowledge from consumer and competitive intelligence), and relational (e.g. relationships with suppliers and customers).

Each firm in the marketplace will have at least some resources that are unique to it (e.g. very knowledgeable employees, efficient production processes, etc.) that could constitute a comparative advantage in resources that could lead to positions of advantage (i.e. cells 2, 3, and 6 in Figure 2) in the marketplace. Some of these resources are not easily copied or acquired (i.e. they are relatively immobile). Therefore, such resources (e.g. culture and processes) may be a source of long-term competitive advantage in the marketplace.

Just as international trade theory recognizes that nations have heterogeneous, immobile resources, and it focuses on the importance of comparative advantages in resources to explain the benefits of trade, R-A theory recognizes that many of the resources of firms within the same industry are significantly heterogeneous and relatively immobile. Therefore, analogous to nations, some firms will have a comparative advantage and others a comparative disadvantage in efficiently and/or effectively producing particular market offerings that have value for particular market segments.

Specifically, as shown in Figure 1 and further explicated in Figure 2, when firms have a comparative advantage in resources they will occupy marketplace positions of 
competitive advantage for some market segment(s). Marketplace positions of competitive advantage then result in superior financial performance. Similarly, when firms have a comparative disadvantage in resources they will occupy positions of competitive disadvantage, which will then produce inferior financial performance. Therefore, firms compete for comparative advantages in resources that will yield marketplace positions of competitive advantage for some market segment(s) and, thereby, superior financial performance. As Figure 1 shows, how well competitive processes work is significantly influenced by five environmental factors:

1 the societal resources on which firms draw;

2 the societal institutions that form the "rules of the game" (North, 1990);

3 the actions of competitors;

4 the behaviors of consumers and suppliers; and

5 public policy decisions.

Consistent with its Schumpeterian heritage, R-A theory places great emphasis on innovation, both proactive and reactive. The former is innovation by firms that, although motivated by the expectation of superior financial performance, is not prompted by specific competitive pressures - it is genuinely entrepreneurial in the classic sense of entrepreneur. In contrast, the latter is innovation that is directly prompted by the learning process of firms' competing for the patronage of market segments. Both proactive and reactive innovation contribute to the dynamism of R-A competition.

Firms (attempt to) learn in many ways - by formal market research, seeking out competitive intelligence, dissecting competitors' products, benchmarking, and test marketing. What R-A theory adds to extant work is how the process of competition itself contributes to organizational learning. As the feedback loops in Figure 1 show, firms learn through competition as a result of the feedback from relative financial performance signaling relative market position, which in turn signals relative resources. When firms competing for a market segment learn from their inferior financial performance that they occupy positions of competitive disadvantage (see Figure 2), they attempt to neutralize and/or leapfrog the advantaged firm(s) by acquisition and/or innovation. That is, they attempt to acquire the same resource as the advantaged firm(s) and/or they attempt to innovate by imitating the resource, finding an equivalent resource, or finding (creating) a superior resource. Here, "superior" implies that the innovating firm's new resource enables it to surpass the previously advantaged competitor in terms of either relative costs (i.e. an efficiency advantage), or relative value (i.e. an effectiveness advantage), or both.

Firms occupying positions of competitive advantage can continue to do so if:

- they continue to reinvest in the resources that produced the competitive advantage; and

- rivals' acquisition and innovation efforts fail.

Rivals will fail (or take a long time to succeed) when an advantaged firm's resources are either protected by such societal institutions as patents or the advantage-producing resources are causally ambiguous, socially or technologically complex, tacit, or have time compression diseconomies.

Competition, then, is viewed as an evolutionary, disequilibrium-provoking process. It consists of the constant struggle among firms for comparative advantages in resources that will yield marketplace positions of competitive advantage and, thereby, superior financial performance. Once a firm's comparative advantage in resources enables it to achieve superior performance through a position of competitive advantage in some market segment(s), competitors attempt to neutralize and/or leapfrog the advantaged firm through acquisition, imitation, substitution, or major innovation. RA theory is, therefore, inherently dynamic. Disequilibrium, not equilibrium, is the norm. In the terminology of Hodgson's (1993) taxonomy of evolutionary economic theories, R-A theory is non-consummatory: it has no end-stage, only a never-ending process of change. The implication is that, though market-based economies are moving, they are not moving toward some final state, such as a Pareto-optimal, general equilibrium.

\section{R-A theory and conceptual frameworks}

In this section, we propose five conceptual frameworks that are drawn/developed from R-A theory that can be used for managerial action.

\section{The schematic of R-A theory}

The schematic shown as Figure 1 can be a conceptual framework that can help managers in thinking about strategy problems. The figure provides managers with a strong visual articulation of how competition works. That is, managers can see that:

1 competition is the disequilibrating, ongoing process that consists of the constant struggle among firms for a comparative advantage in resources that will yield a marketplace position of competitive advantage and, thereby, superior financial performance;

2 firms learn through competition as a result of feedback from relative financial performance "signaling" relative market position, which, in turn signals relative resources; and

3 competitive processes are significantly influenced by five environmental factors:

- the societal resources on which firms draw;

- the societal institutions that frame the rules of the game;

- the actions of competitors;

- the behaviors of consumers and suppliers; and

- public policy decisions.

This schematic provides a strong visualization of how competition works and how managers should focus on particular elements of the schematic based on their specific contexts. For example, in a firm that offers snack foods, managers could focus on changing consumer preferences with reference to healthy and/or organic snacks. Consequently, managerial actions concerning securing resources that help the firm develop healthy and/or organic snacks could lead to a comparative advantage in resources and, therefore, superior financial performance. Therefore, this schematic can significantly help the managers' analyses.

\section{Competitive position matrix}

As shown in Figure 2, the marketplace position of competitive advantage identified as cell 3 results from the firm, relative to 
its competitors, having a resource assortment that enables it to produce an offering for some market segment(s) that:

- is perceived to be of superior value; and

- is produced at lower costs.

Managers can use this figure to place relevant firms on the matrix and then could start analyzing how their firm can develop business and marketing strategies for moving from the cells on the (lower) left to the cells on the (upper) right. This can be extremely helpful for managers' analyzing their firms' and competitors' positions, understanding the history of the firm and/or industry, and developing new market offerings with the goal of developing a comparative advantage(s) in resource(s) that could lead to competitive advantage(s) in the marketplace.

\section{Firm resources}

For R-A theory, resources are the tangible and intangible entities available to the firm that enable it to produce efficiently and/or effectively a market offering that has value for some marketing segment(s). Thus, resources are not just land, labor, and capital, as in neoclassical theory. Rather, resources can be categorized as financial (e.g. cash resources, access to financial markets), physical (e.g. plant, equipment), legal (e.g. trademarks, licenses), human (e.g. the skills and knowledge of individual employees), organizational (e.g. competences, controls, policies, culture), informational (e.g. knowledge from consumer and competitive intelligence), and relational (e.g. relationships with suppliers and customers). For managers, the list of resources provided by R-A theory provides a good starting point for thinking about, for example, strategic resources, brand equity, the importance of corporate culture, and the role of relationships and alliances in strategy. In short, the list is a starting point for the question: who (what) are we as a firm?

\section{Higher-order resources}

R-A theory defines higher-order resources as distinct packages of basic resources. For R-A theory, competences or capabilities are higher-order resources. That is, they are "socially complex, interconnected combinations of tangible basic resources (e.g., specific machinery, computer software and hardware) and intangible basic resources (e.g., specific organizational policies and procedures and the skills, knowledge, and experience of specific employees) that fit together coherently in a synergistic manner to enable firms to produce efficiently and/or effectively valued market offerings" (Hunt, 2000a, p. 188). The point to stress is that "higher-order resources" provides a conceptual framework that assists managers in understanding how competences and capabilities are related to specific firm situations, contexts, and problems. For illustrative purposes, we provide a brief discussion of four higher-order resources with reference to the firm's overall marketing strategy:

1 market knowledge competence;

2 market sensing capability;

3 market planning capability; and

4 marketing strategy making capability.

We then discuss four higher-order resources that can facilitate managerial action with reference to the firm's overall business strategy:

1 absorptive capacity;

2 market-focused strategic flexibility;

3 learning platform capability; and

4 organizational learning capability.
$\mathrm{Li}$ and Calantone (1998, p. 14) define market knowledge competence as "the processes that generate and integrate market knowledge". For them, processes imply a series of activities that involves interconnected bundles of skills and collective learning. $\mathrm{Li}$ and Calantone (1998) conceptualize market knowledge competence as having three components:

1 customer knowledge process;

2 marketing-R\&D interface; and

3 competitor knowledge process.

Day (1994, p. 43) argues that market driven firms have a market sensing capability. That is, in market driven firms, "the processes for gathering, interpreting, and using information are more systematic, thoughtful, and anticipatory than in other firms".

Slotegraaf and Dickson (2004, p. 373) define marketing planning capability as "the ability to anticipate and respond to the market environment in order to direct a firm's resources and actions in ways that align the firm with environment and achieve the firm's financial goals". Measuring marketing planning capability as formative construct that involves competencies in market scanning, market situation/ environment analysis, matching firm strengths to market opportunities, meshing programs to market realities, implementing marketing programs, marketing budgeting/ allocating resources, and program performance tracking, they note that marketing planning capability positively influences firm performance. Following Menon et al. (1999, p. 21), marketing strategy making (MSM) capability involves "a complex set of activities, processes, and routines involved in the design and execution of marketing plans". All the four higher-order resources can influence all aspects of a firm's marketing strategy. Next, we turn our attention to higherorder resources in the context of business strategy.

\section{Absorptive capacity}

Reviewing the literature on absorptive capacity, Zahra and George (2002) reconceptualized absorptive capacity as having two components:

1 potential absorptive capacity; and

2 realized absorptive capacity.

While potential absorptive capacity makes the firm receptive to acquiring and assimilating external knowledge, realized absorptive capacity is a function of the transformation and exploitation capabilities of the firm. Zahra and George (2002) note that the two components of absorptive capacity have a role in providing firms with competitive advantage through positive influences on strategic flexibility, innovation, and performance. Jansen et al. (2005) recently investigated how organizational antecedents help in managing potential and realized absorptive capacity.

Market-focused strategic flexibility

Johnson et al. (2003, p.77) define market-focused strategic flexibility as "the firm's intent and capabilities to generate firmspecific real options for the configuration and reconfiguration of appreciably superior customer value propositions". That is, capabilities and intent are two components of market-focused strategic flexibility. For them, firm capabilities involve the identification of resources, the acquisition of resources, the deployment of resources, and the identification of options. Furthermore, they suggest that market-focused strategic flexibility is positively related to both short-term and long-term firm performance. 


\section{Learning platform capability}

For Johnson and Sohi (2003), a learning platform has three components - learning intent, transparency, and receptivity, which are, respectively, the firm's:

1 desire to internalize knowledge into the firm's knowledge stocks;

2 interfaces between functional areas, levels of management, and other relevant work group such as the teams that work together in boundary spanning activities; and

3 capacity or potential to learn.

This learning platform capability indirectly influences the firm's relational outcome such as effectiveness/efficiency and commitment through dissemination and shared interpretation of information.

\section{Organizational learning capability}

Organizational learning can be conceptualized as the "capability of as organization to process knowledge - in other words, to create, acquire, transfer, and integrate knowledge, and to modify its behavior to reflect the new cognitive situation, with a view to improving its performance" (Jerez-Gomez et al., p. 716). Organizational capability has four dimensions:

1 managerial commitment;

2 systems perspective;

3 openness and experimentation; and

4 knowledge transfer and integration.

Furthermore, although the identified dimensions are different, they are also related. For example, Jerez-Gomez and colleagues note that there is interaction between openness and experimentation and knowledge transfer and integration.

As per the firm's requirement and contexts, managers can evaluate different kinds of higher-order resources for managerial action. Though we have identified higher-order resources for marketing and business strategy in general, managers could pursue specific higher-order resources for specific business and marketing strategies. For example, for a specific form of marketing strategy such as brand equity strategy, managers will be required to look at some additional higher-order resources. Similarly, for a specific form of business strategy such as knowledge-based strategy, managers will be required to look at some additional higher-order resources. The point to be stressed here is that R-A theory's concept of "higher-order resources" provides the foundation for understanding both marketing and overall business competences and capabilities.

\section{Firm Resources and External Environment (FREE) framework}

In this section, we introduce - briefly because of space limitations - a new framework based on R-A theory that can be viewed as an alternative to the SWOT framework. The Firm Resources and External Environment (FREE) framework requires analysis in two parts:

1 analyzing the firm's resources; and

2 analyzing the external environment using the five environmental factors shown in Figure 1 (the societal resources on which firms draw, the societal institutions that frame the rules of the game, the actions of competitors, the behaviors of consumers and suppliers, and public policy decisions).
Before we discuss the specific steps involved to use the framework, readers should note that we use "firm resources" instead of "internal resources" because the framework requires managers to consider all the resources that the firm has access to (whether they are internal or external to the firm).

Users of the FREE framework need to follow four specific steps:

1 determine the existing and potential market segment(s) relevant to the firm;

2 analyze the firm as a bundle of available resources, nonresources, contra-resources, and higher-order resources;

3 analyze the external environment in terms of the five environmental factors - i.e. the societal resources on which the firm can draw, the societal institutions that frame the rules of the game, the strategies of competitors, the behaviors of consumers and suppliers, and relevant public policy; and

4 use the results from steps 1, 2, and 3 for strategy recognition, understanding, creation, selection, implementation, and modification (see Table III for specific details of how managers can use the FREE framework).

Note that the second step introduces two concepts not typically found outside the FREE framework:

1 non-resources; and

2 contra-resources.

While non-resources are tangible and intangible entities that are available to the firm that do not enable and/or inhibit the firm, contra-resources are tangible and intangible entities that are available to the firm that actually inhibit the firm from producing efficiently and/or effectively market offerings that have value for some marketing segment(s).

Also, managers are cautioned to the fact that whether an entity is a resource or not depends on - is contingent on specific firm circumstances. For example, consider the policy of "permanent employment" - that is, the policy of a firm guaranteeing jobs for (most) employees "through thick and thin". For some firms in some circumstances, the policy might foster organizational commitment, and hence motivate employees to work both harder and smarter. Under these circumstances, the permanent employment policy would be a resource, i.e. it would contribute to the firm's ability to produce, efficiently and/or effectively, valued market offerings. Under other circumstances, the policy might contribute to employees' lethargy, thus making it a non-resource or, even worse, a contra-resource (and actually inhibiting the firm's efforts at producing valued market offerings). As noted earlier, higher-order resources are distinct packages of basic resources. It is imperative that managers deliberate on distinct combinations of basic resources that make the firm efficient and/or effective to solve firm-specific problems.

Although the development of the FREE framework is in its infancy, it appears that it might - when more completely developed - overcome some of the problems that the users of SWOT often face. First, the problem of coming up with superficial, descriptive lists, with changing criteria is potentially overcome because for entities to qualify as resources, they must contribute to enabling the firm to produce its market offering(s) effectively and/or efficiently. The same holds for non-resources, contra-resources, and higher-order resources. Second, the problem of the analyses 
Table III The FREE framework

\begin{tabular}{|c|c|c|}
\hline Steps & Required knowledge & Tasks to be performed by managers \\
\hline $\begin{array}{l}\text { 1. Determine the market segment(s) relevant } \\
\text { to the firm }\end{array}$ & $\begin{array}{l}\text { Understanding competition as the constant } \\
\text { struggle among firms for comparative advantages } \\
\text { in resources that will yield a marketplace position } \\
\text { of competitive advantage and, thereby, superior } \\
\text { financial performance; Knowledge and } \\
\text { understanding of competition as a knowledge } \\
\text { discovery process, efficiency and effectiveness } \\
\text { advantages, and competitive advantage }\end{array}$ & $\begin{array}{l}\text { Assess the segmentation bases and relevant } \\
\text { information pertaining to the problems facing the } \\
\text { firm and determine the market segment(s) the firm } \\
\text { should be competing for }\end{array}$ \\
\hline 2. Analyze the firm as a bundle of resources & $\begin{array}{l}\text { Knowledge and understanding of resources, non- } \\
\text { resources, contra-resources, and higher-order } \\
\text { resources }\end{array}$ & $\begin{array}{l}\text { Analyze the firm as a bundle of resources, non- } \\
\text { resources, contra-resources, and higher-order } \\
\text { resources. Constantly think about how the bundle } \\
\text { resonates with efficiently and/or effectively } \\
\text { producing market offerings for certain market } \\
\text { segment(s) }\end{array}$ \\
\hline $\begin{array}{l}\text { 3. Analyze the external environment in terms } \\
\text { of the five environmental facts }\end{array}$ & $\begin{array}{l}\text { Knowledge and understanding of the five } \\
\text { environmental factors: the societal resources on } \\
\text { which firms draw, the societal institutions that } \\
\text { frame the rules of the game, the actions of } \\
\text { competitors, the behaviors of consumers and } \\
\text { suppliers, and public policy decisions }\end{array}$ & $\begin{array}{l}\text { Analyze how the relevant environmental factors } \\
\text { for the case or project influence the process of } \\
\text { competition. Also, analyze competitors and } \\
\text { suppliers as bundles of resources }\end{array}$ \\
\hline $\begin{array}{l}\text { 4. Use the results from steps } 1,2 \text {, and } 3 \text { for } \\
\text { strategy recognition, understanding, } \\
\text { creation, selection, implementation, and } \\
\text { modification }\end{array}$ & $\begin{array}{l}\text { Knowledge and understanding of firm's strategy } \\
\text { and the concepts of strategy recognition, } \\
\text { understanding, creation, selection, } \\
\text { implementation, and modification }\end{array}$ & $\begin{array}{l}\text { Articulate the implications of the external } \\
\text { environment for the firm, and use the results of the } \\
\text { analyses for strategy recognition, understanding, } \\
\text { creation, selection, implementation, and } \\
\text { modification }\end{array}$ \\
\hline
\end{tabular}

not figuring in subsequent market strategy development is potentially overcome, as managers are required to use the results of their analysis for strategy recognition, understanding, creation, selection, implementation, and modification. Third, the over-subjectivity in the analyses and the compiler bias are potentially overcome, as all the concepts are tightly defined. Fourth, the framework springs from a positive, integrative theory that can ground business and marketing strategy, and, therefore, is consistent with the most general theory of how the process of competition works.

\section{Conclusion}

Conceptual frameworks that facilitate managerial action are often thought to be more useful than theories. In this paper, we identify several conceptual frameworks from business and marketing strategy literatures and discuss the most popular and widely used, SWOT framework. In discussing the SWOT framework, we explicate the advantages put forth by proponents and the disadvantages offered by critics. Noting that conceptual frameworks that have positive theoretical foundations are more useful than frameworks that do not, we offer five new conceptual frameworks. These frameworks are based on resource-advantage theory, which is a general theory of competition that provides an integrative, positive, theoretical foundation for business and marketing strategy.

Because R-A theory is a general theory of competition, it shows managers how business and marketing strategy "fit into" the broader issues of competition. Furthermore, R-A theory, through its five conceptual frameworks, benefits managerial action by helping managers in thinking about business and marketing strategy. This, in turn, helps them in systematically analyzing and solving business and marketing strategy problems. Specifically, the FREE framework though only sketched here - has some advantages over SWOT and may potentially overcome some of the problems with the usage of SWOT. We offer the five conceptual frameworks, including the FREE framework, as potential facilitators of managerial action.

\section{References}

Arnett, D.B. and Hunt, S.D. (2002), "Competitive irrationality: the influence of moral philosophy", Business Ethics Quarterly, Vol. 12 No. 3, pp. 279-303.

Biggadike, R.E. (1981), "The contributions of marketing to strategic management", Academy of Management Review, Vol. 6 No. 4, pp. 621-32.

Day, G.S. (1994), "The capabilities of market-driven organizations", Fournal of Marketing, Vol. 58, October, pp. 37-52.

Day, G.S. and Montgomery, D.B. (1999), "Charting new directions for marketing", fournal of Marketing, Vol. 63, Special Issue, pp. 3-13.

Foss, N. (1993), "Theories of the firm: contractual and competence perspectives", fournal of Evolutionary Economics, Vol. 3, pp. 127-44.

Foss, N.J. (2000), "The dangers and attractions of theoretical eclecticism", Fournal of Macromarketing, Vol. 20, June, pp. 65-7.

Garda, R.A. (1988), "Comment by Robert A. Garda", Fournal of Marketing, Vol. 52 No. 4, pp. 32-41. 
Ghoshal, S. and Bartlett, C.A. (1994), "Linking organizational context and managerial action: the dimensions of quality of management", Strategic Management fournal, Vol. 15, pp. 91-112.

Haynes, P.J. and Helms, M.M. (1991), "Strengthening the relevance of the marketing strategy course by using a career planning exercise", fournal of Marketing Education, Vol. 13 No. 3, pp. 66-75.

Henson, S.W., Kennett, P.A. and Kennedy, K.N. (2003), "Web-based cases in strategic marketing", fournal of Marketing Education, Vol. 25 No. 3, pp. 250-9.

Hill, T. and Westbrook, R. (1997), "SWOT analysis: it's time for a product recall”, Long Range Planning, Vol. 30 No. 1, pp. 46-52.

Hodgson, G.M. (1993), Economics and Evolution, University of Michigan Press, Ann Arbor, MI.

Hodgson, G.M. (2000), "The marketing of wisdom: resource-advantage theory", fournal of Macromarketing, Vol. 20, June, pp. 68-72.

Hunt, S.D. (1995), "The resource-advantage theory of competition: toward explaining productivity and economic growth", fournal of Management Inquiry, Vol. 4, December, pp. 317-32.

Hunt, S.D. (1997a), “Competing through relationships: grounding relationship marketing in resource advantage theory", fournal of Marketing Management, Vol. 13, pp. 431-45.

Hunt, S.D. (1997b), "Evolutionary economics, endogenous growth models, and resource-advantage theory", Eastern Economic fournal, Vol. 23 No. 4, pp. 425-39.

Hunt, S.D. (1997c), "Resource-advantage theory: an evolutionary theory of competitive firm behavior?", The fournal of Economic Issues, Vol. 31, March, pp. 59-77.

Hunt, S.D. (1997d), "Resource-advantage theory and the wealth of nations", The fournal of Socio-Economics, Vol. 26 No. 4, pp. 335-57.

Hunt, S.D. (1998), "Productivity, economic growth, and competition: resource allocation or resource creation?", Business and the Contemporary World, Vol. 10 No. 3, pp. 367-94.

Hunt, S.D. (1999), “The strategic imperative and sustainable competitive advantage: public policy and resource advantage theory", Fournal of Academy of Marketing Science, Vol. 27 No. 2, pp. 144-59.

Hunt, S.D. (2000a), "The competence-based, resourceadvantage, and neoclassical theories of competition: toward a synthesis", in Sanchez, R. and Heene, A. (Eds), Competence-Based Strategic Management: Theory and Research, JAI Press, Greenwich, CT, pp. 177-208.

Hunt, S.D. (2000b), A General Theory of Competition: Resources, Competences, Productivity, Economic Growth, Sage Publications, Thousand Oaks, CA.

Hunt, S.D. (2000c), "A general theory of competition: too eclectic or not eclectic enough? Too incremental or not incremental enough? Too neoclassical or not neoclassical enough?”, fournal of Macromarketing, Vol. 20 No. 1, pp. 77-81.

Hunt, S.D. (2000d), "Synthesizing resource-based, evolutionary and neoclassical thought: resource-advantage theory as a general theory of competition", in Foss, N.J. and Robertson, P. (Eds), Resources, Technology, and Strategy, Routledge, London, pp. 53-79.
Hunt, S.D. (2001), "A general theory of competition: issues, answers, and an invitation", European fournal of Marketing, Vol. 35 Nos 5/6, pp. 524-48.

Hunt, S.D. (2002a), Foundations of Marketing Theory: Toward a General Theory of Marketing, M.E. Sharpe, Armonk, NY.

Hunt, S.D. (2002b), "Marketing and a general theory of competition", fournal of Marketing Management, Vol. 18 Nos $1 / 2$, pp. 239-47.

Hunt, S.D. (2002c), "Resource-advantage theory and Austrian economics", in Foss, N.J. and Klein, P. (Eds), Entrepreneurship and the Firm: Austrian Perspectives on Economic Organization, Edward Elgar, Cheltenham, pp. 248-72.

Hunt, S.D. (2011), "Sustainable marketing, equity, and economic growth: a resource-advantage, economic freedom approach", Fournal of the Academy of Marketing Science, Vol. 39 No. 1, pp. 7-20.

Hunt, S.D. and Arnett, D.B. (2001), "Competition as an evolutionary process and antitrust policy", fournal of Public Policy and Marketing, Vol. 20 No. 1, pp. 15-25.

Hunt, S.D. and Arnett, D.B. (2003), "Resource-advantage theory and embeddedness: explaining R-A theory's explanatory success", fournal of Marketing Theory and Practice, Vol. Winter, pp. 1-16.

Hunt, S.D. and Arnett, D.B. (2004), "Market segmentation strategy, competitive advantage, and public policy: grounding segmentation strategy in resource-advantage theory", Australasian Marketing fournal, Vol. 12 No. 1, pp. 7-25.

Hunt, S.D. and Derozier, C. (2004), "The normative imperatives of business and marketing strategy: grounding strategy in resource-advantage theory", fournal of Business \& Industrial Marketing, Vol. 19 No. 1, pp. 5-22.

Hunt, S.D. and Duhan, D.F. (2002), "Competition in the third millennium: efficiency or effectiveness?", fournal of Business Research, Vol. 55 No. 2, pp. 97-102.

Hunt, S.D. and Lambe, C.J. (2000), “Marketing's contribution to business strategy: market orientation, relationship marketing, and resource-advantage theory", International fournal of Management Reviews, Vol. 2 No. 1, pp. 17-44.

Hunt, S.D. and Madhavaram, S. (2006), "Teaching marketing strategy: using resource-advantage theory as an integrative theoretical foundation", Fournal of Marketing Education, Vol. 28 No. 2, pp. 93-105.

Hunt, S.D. and Morgan, R.M. (1995), "The comparative advantage theory of competition", fournal of Marketing, Vol. 59, April, pp. 1-15.

Hunt, S.D. and Morgan, R.M. (1996), "The resourceadvantage theory of competition: dynamics, path dependencies, and evolutionary dimensions", fournal of Marketing, Vol. 60, October, pp. 107-14.

Hunt, S.D. and Morgan, R.M. (1997), "Resource-advantage theory: a snake swallowing its tail or a general theory of competition?", fournal of Marketing, Vol. 61, October, pp. 74-82.

Hunt, S.D., Lambe, C.J. and Wittman, C.M. (2002), "A theory and model of business alliance success", fournal of Relationship Marketing, Vol. 1 No. 1, pp. 17-36.

Jansen, J.P., Van Den Bosch, F.A.J. and Volberda, H.W. (2005), "Managing potential and realized absorptive capacity: how do organizational antecedents matter?", 
Academy of Management fournal, Vol. 48 No. 6, pp. 999-1015.

Johnson, J.L. and Sohi, R.S. (2003), "The development of interfirm partnering competence: platforms for learning, learning activities, and consequences of learning", fournal of Business Research, Vol. 56, pp. 757-66.

Johnson, J.L., Lee, R.P., Saini, A. and Grohmann, B. (2003), "Market-focused strategic flexibility: conceptual advances and an integrative model", fournal of the Academy of Marketing Science, Vol. 31 No. 1, pp. 74-89.

Li, T. and Calantone, R. (1998), "The impact of market knowledge competence on new product advantage: conceptualization and empirical examination", fournal of Marketing, Vol. 62, October, pp. 13-29.

Menon, A., Bharadwaj, S.G., Adidam, P.T. and Edison, S.W. (1998), "Antecedents and consequences of marketing strategy making: a model and a test", fournal of Marketing, Vol. 63 No. 2, pp. 18-41.

Morgan, R.E. and Hunt, S.D. (2002), "Determining marketing strategy: a cybernetic systems approach to scenario planning", European fournal of Marketing, Vol. 36 No. 4, pp. $450-78$.

North, D.C. (1990), Institutions, Institutional Change, and Economic Performance, University of Cambridge, Cambridge.

Panagiotou, G. (2003), "Bringing SWOT into focus", Business Strategy Review, Vol. 14 No. 2, pp. 8-10.

Peterson, R.T. (1987), “A marketing history perspective for the marketing management class", fournal of Marketing Education, Vol. 9 No. 1, pp. 31-6.

Pickton, D.W. and Wright, S. (1998), "What's SWOT in strategic analysis", Strategic Change, Vol. 7, pp. 101-9.

Porter, M.E. (1991), "Towards a dynamic theory of strategy", Strategic Management Fournal, Vol. 12, pp. 95-117.

Rajgopal, S., Venkatachalam, M. and Kotha, S. (2002), "Managerial actions, stock returns, and earnings: the case of business-to-business internet firms", Fournal of Accounting Research, Vol. 40 No. 2, pp. 529-56.

Rossiter, J.R. (2001), "What is marketing knowledge? Stage I: forms of marketing knowledge", Marketing Theory, Vol. 1 No. 1, pp. 9-26.

Slotegraaf, R.J. and Dickson, P.R. (2004), "The paradox of a marketing planning capability", Fournal of the Academy of Marketing Science, Vol. 32 No. 4, pp. 371-85.

Teece, D. and Pisano, G. (1994), "The dynamic capabilities of firms: an introduction", Industrial and Corporate Change, Vol. 3, pp. 537-56.

Van Doren, D.C. and Smith, F.B. (1999), "Scenarioplanning: a new approach to teaching marketing strategy", Fournal of Marketing Education, Vol. 21 No. 2, pp. 146-55.

Venkataraman, N. and Prescott, J.E. (1990), "Environmentstrategy alignment: an empirical test of its performance implications", Strategic Management fournal, Vol. 1, pp. 1-23.

Zahra, S.A. and George, G. (2002), "Absorptive capacity: a review, reconceptualization, and extension", Academy of Management Review, Vol. 27 No. 2, pp. 185-203.

\section{Further reading}

Hunt, S.D. (1992), "Marketing is ...", Fournal of the Academy of Marketing Science, Vol. 20, Fall, pp. 301-11.

Jerez-Gomez, P., Cespedes-Lorente, J. and Valle-Cabrera, R. (2005), "Organizational learning capability: a proposal of measurement", Fournal of Business Research, Vol. 58, pp. 715-25.

\section{About the authors}

Shelby D. Hunt is the Jerry S. Rawls and P.W. Horn Professor of Marketing at Texas Tech University, Lubbock, Texas. A past editor of Fournal of Marketing (1985-1987), he is the author of numerous books, including Marketing Theory: Foundations, Controversy, Strategy, Resource-Advantage Theory (M.E. Sharpe, 2010) and A General Theory of Competition: Resources, Competences, Productivity, Economic Growth (Sage Publications, 2000). One of the 250 most frequently cited researchers in economics and business (Thompson-ISI), he has written numerous articles on competitive theory, strategy, macromarketing, ethics, relationship marketing, channels of distribution, philosophy of science, and marketing theory. Three of his fournal of Marketing articles - "The nature and scope of marketing" (1976), "General theories and fundamental explananda of marketing" (1983), and, with Robert M. Morgan, "The comparative advantage theory of competition" (1995) - won the Harold H. Maynard Award for the "best article on marketing theory". The "comparative advantage theory" article also won the 2004 Sheth Foundation/Fournal of Marketing award for its "long term contributions to the field of marketing". His 2011 fournal of the Academy of Marketing Science article "Sustainable marketing, equity, and economic growth: a resourceadvantage, economic freedom approach" won the Sheth Foundation Award for Best Paper. His 1994 "Commitment and trust" Fournal of Marketing article, with Robert M. Morgan, was the most highly cited article in economics and business in the decade 1993-2003 (Thomson-ISI). In 2011, Sage Publications published the ten-volume set, Legends in Marketing: Shelby D. Hunt, which includes 132 of Hunt's articles and 41 commentaries on his work by distinguished scholars. Shelby D. Hunt is the corresponding author and can be contacted at: shelby.hunt@ttu.edu

Sreedhar Madhavaram (PhD, Texas Tech University) is an Associate Professor of Marketing at Cleveland State University. His work has been published or has been accepted for publication in Industrial Marketing Management, Fournal of Advertising, Fournal of Business \& Industrial Marketing, Fournal of Marketing Education, Fournal of Personal Selling $\mathcal{E}$ Sales Management, Fournal of the Academy of Marketing Science, Marketing Education Review, Psychology $\mathcal{E}$ Marketing, and others. A frequent presenter at national and international conferences, his research interests include marketing strategy, marketing theory and concepts, marketing communications, marketing pedagogy, organizational knowledge, and sales management. 